\title{
Gaining insight into Clipperton's lagoon hydrology using tritium
}

\author{
Philippe Jean-Baptiste ${ }^{\mathrm{a},{ }^{*}}$, Elise Fourré ${ }^{\mathrm{a}}$, Jean-Luc Charlou ${ }^{\mathrm{b}}$, Jean-Pierre Donval ${ }^{\mathrm{b}}$ and Thierry \\ Corrège ${ }^{c}$
}

\author{
a LSCE, CEA-CNRS-IPSL, CEA/Saclay, 91191 Gif-sur-Yvette, France \\ ${ }^{\mathrm{b}}$ IFREMER, DRO-GM, Centre de Brest, Plouzané, France \\ ${ }^{c}$ UMR 5805, CNRS, Université de Bordeaux I, Talence, France
}

\section{*: Corresponding author : Philippe Jean-Baptiste, email address : philippe.jean-baptiste@cea.fr}

\begin{abstract}
:
Historical descriptions of the Clipperton lagoon appear to converge on the fact that it became isolated from the surrounding ocean around 1858. Since then, because of the high precipitation rate which largely exceeds evaporation in this region of the eastern tropical Pacific, a brackish lens has formed on top of the saline oceanic waters. In 1980, literature data show that the thickness of this water body was reaching $14 \mathrm{~m}$. During the 2005 Etienne's Clipperton expedition, we collected lagoon water on two vertical profiles. Salinity, $\delta^{18} \mathrm{O}$ and tritium analyses were performed on these samples with the objective of gaining further insight into the lagoon hydrology and age of the deep waters. The upper $15 \mathrm{~m}$ were characterized by low salinities $(5.4 \pm 0.2)$, and $\delta^{18} \mathrm{O}$ and tritium values typical of local precipitation. At depth, waters had salinity and $\delta^{18} \mathrm{O}$ similar to oceanic surface waters but with low tritium concentrations, hence pointing to quite isolated waters representing a remnant of marine waters when the lagoon was still communicating with the ocean. At lagoon closure, the excess of precipitation over evaporation raised the lagoon level, thus creating a hydraulic pressure head which favored salt expulsion through the permeable walls of the atoll. A simple geohydrological modeling of this salt expulsion process based on Darcy's law describes reasonably well the time-evolution of the brackish lens. Tritium is used to discuss the main physical processes potentially involved in the slow ventilation of the halocline and deep saline layer, including vertical diffusion, sinking of salty surface water intrusions and deep horizontal exchange through fissures in the limestone. These different mechanisms give reasonable results, which are all compatible with available salinity and isotopic data $\left(\delta^{18} \mathrm{O}\right.$ and tritium), and therefore are all plausible candidates. Unfortunately, the lack of a detailed description of the vertical tritium profile in the halocline, between $-15 \mathrm{~m}$ and $-20 \mathrm{~m}$, precludes any further quantification of their respective role in the ventilation process.
\end{abstract}

Keywords: Clipperton atoll; enclosed lagoon hydrology; tritium; oxygen isotopes 


\section{Introduction}

The French island of Clipperton is a small barren atoll ( $\sim 12 \mathrm{~km}$ in circumference) located at $10^{\circ} 18 \mathrm{~N} / 109^{\circ} 13 \mathrm{~W}$ in the eastern Pacific. In many respects, the place is quite peculiar. It is the easternmost coral atoll in the Pacific Ocean, approximately $1200 \mathrm{~km}$ off the coast of Mexico. Unlike most Indo-Pacific atoll lagoons, which can exchange water with the surrounding ocean though "passes" in the atoll rim, the lagoon of Clipperton has been fully enclosed for about 150 years (Sachet 1962). As a consequence, it has almost fresh surface waters resulting from its isolation and heavy rainfall. During its short chaotic history (Skaggs 1989), Clipperton island got the reputation of being one of the most obscure, isolated and unpleasant places on earth. This uninhabited island was settled late in the nineteenth century by miners of the Oceanic Phosphate Company who processed bird droppings as fertilizer, joined up in 1908 by a small garrison of Mexican soldiers with their family. In this tiny tropical hell, many became desperate to leave, convinced that the island was driving them mad. During World War I, the islanders were cut off from the mainland and died little by little from scurvy and malnutrition. The survivors, a handful of women and children, became ruled by a madman (the light keeper) who proclaimed himself "King of Clipperton", raping whomever he wanted and murdering any who resisted. Eventually, the women killed him, putting his reign of terror to an end. By July 1917, three women and eight children were the only ones alive and were picked up by the USS “Yorktown". Its last permanent occupation was in 1944/45 when President Roosevelt ordered the US Navy to seize the atoll. Soon after, World War II ended and the atoll was abandoned. It has been only visited since then by the French Navy and occasional scientific expeditions. The most comprehensive description of the island is given by Sachet (1962) who reports in detail the results of the expedition organized by the Scripps Institution of Oceanography (SIO) in 1958. The atoll rim, made of coral sand and fragments, is no higher than $4 \mathrm{~m}$, with the lowest point rising only $0.45 \mathrm{~m}$ 
above high tide mean level (Sachet 1962), except a volcanic outcrop, the Clipperton Rock, culminating at $29 \mathrm{~m}$ (Fig.1). Its width varies between $45 \mathrm{~m}$ and a few hundreds of metres. Much of the lagoon is between $2 \mathrm{~m}$ and $5 \mathrm{~m}$ deep, with some deeper basins (reaching between $30 \mathrm{~m}$ and $45 \mathrm{~m}$ ) and one deep hole, "le Trou Sans Fond" (TSF) meaning "the Bottomless Pit", a karstic structure located in the southern part of the lagoon and probably formed during the glacial periods when the reef was exposed (Sachet 1962). The main feature of the lagoon hydrology is its fresh water body, which extends to a depth of about $15 \mathrm{~m}$ (see detailed discussion below), floating on top of saline waters smelling strongly of hydrogen sulfide due to organic matter degradation and extremely corrosive to divers' skins. These saline waters are probably a remnant of the lagoon marine waters from the period when the lagoon was still open to the ocean (Sachet 1962). However, it is also possible that these lagoon deep waters may communicate and exchange at depth with surrounding ocean waters through a network of fissures and cracks.

Although lagoon hydrology was out of the scope of the Jean-Louis Etienne's 2005 expedition (Etienne 2005), we got the opportunity to collect some water samples : 14 samples were taken in Pyrex bottles opened at the chosen depth by a scuba diver (T. Corrège, one of the co-authors) in the TSF and in the "Fosse Occidentale" (FO) or "Western Deep" - see

Fig. 1. Here we report tritium analyses which were performed along with salinity and $\delta^{18} \mathrm{O}$ on these samples, with the objective of getting further insight into the history, origin and residence time of the lagoon deep waters.

\section{The closure of the Clipperton lagoon}

Clipperton's map by Sir Edward Belcher in 1839 (Belcher 1843) shows two openings in the coral ring, one to the North East and one to the South East (Fig. 1 inset). These passes were probably already quite shallow at the time of Belcher's description who wrote : "there 
are two entrances, which at high water may be safe; but at the moment we passed, the surf was too heavy and the reflux showed the rocks bare" (Belcher 1843). About twenty years later, in November 1858, when the French naval officer Lieutenant Le Coat de Kerveguen took possession of the island and proclaimed French ownership on behalf of Emperor Napoléon III, he observed the coral ring was continuous. He also reported that the lagoon waters were saline (French Foreign Office 1912), whereas three years later, an American prospector, John Griswold found that lagoon waters were "potable if brackish" (quoted by Pease 1868). This suggests that the lagoon closure may have occurred shortly before 1858 , probably during one or several violent storms that piled up sand and coral gravel across the shallow openings. The area where these openings were located can still be recognized by the absence of consolidated rocks (Sachet 1962). The passes have remained closed ever since, although ocean waters may pour over the land strip during severe storms. It was envisaged to blow up a break in the reef during US occupation in 1944/45 in order to give ships safe access to the lagoon but World War II ended soon after and this never happened (Skaggs 1989).

Owing to the high precipitation rate in the eastern Pacific relative to evaporation with $(\mathrm{E}$ P) -1.1 $\mathrm{m} \mathrm{yr}^{-1}$ (Woodruff et al. 1987), a fresh water lens may have started to form on top of the heavier saline oceanic waters soon after the lagoon closure (thus explaining Le Coat de Kerveguen and Griswold diverging observations concerning lagoon salinity), raising the lagoon level and thus creating a hydraulic pressure head that progressively forced the saline waters out of the lagoon through its permeable walls (Broc et al. 1998). Based on divers' observations in 2005 of a sharp change in water properties just below $\mathrm{z}=-15 \mathrm{~m}$ (lagoon water below this level becomes extremely corrosive and harmful for divers' skins due to the presence of $\mathrm{H}_{2} \mathrm{~S}$ ), we can conclude that the approximate value of the fresh water body thickness is about $\mathrm{H}=15 \mathrm{~m}$. 
At hydrostatic equilibrium, the thickness $\mathrm{H}$ of the freshwater body would correspond to an additional height of the lagoon level relative to the surrounding ocean $\Delta \mathrm{h}=\mathrm{H} \times\left(\rho_{\mathrm{sw}} / \rho_{0}\right.$ 1) $\sim 0.3 \mathrm{~m}$ where $\rho_{\mathrm{sw}}$ is the density of seawater $\left(\sim 1025 \mathrm{~kg} \mathrm{~m}^{-3}\right)$ and $\rho_{0}$ the density of the freshwater lens $\left(\sim 1000 \mathrm{~kg} \mathrm{~m}^{-3}\right)$. Since the system is not in static but rather in dynamic equilibrium, $+0.3 \mathrm{~m}$ thus represents the minimum lagoon height relative to the mean sea level. Unfortunately, no measurement for $\Delta \mathrm{h}$ is available whatsoever.

The fresh water body appears to have thickened by about one meter since the first accurate salinity measurements in 1980 (Carsin 1980) which display low salinities $(4.4 \pm 0.2)$ down to $-14 \mathrm{~m}$. This suggests that salt expulsion may have proceeded quite rapidly in the first years following lagoon closure and may have slowed down later on, pointing to the likely high permeability of the upper part of the edifice and lower permeability at deeper levels.

Based on the available observations (probable lagoon closure in 1858, freshwater body thickness approximately equal to $14 \mathrm{~m}$ in 1980 and $15 \mathrm{~m}$ in 2005), we have simulated numerically (see Supplementary data) the likely time-evolution of the thickness $\mathrm{H}(\mathrm{t})$ of the freshwater body using Darcy's law which governs flow through porous media :

$$
\Phi=\mathrm{K} \operatorname{grad}(\mathrm{h})
$$

where $\Phi$ is the water flux expelled per unit area of the lagoon wall (in $\left.\mathrm{m}^{3} \mathrm{~m}^{-2} \mathrm{~s}^{-1}\right), \mathrm{K}$ is the hydraulic conductivity (in $\mathrm{m} \mathrm{s}^{-1}$ ) and $\operatorname{grad}(\mathrm{h})$ is the hydraulic head gradient across the porous lagoon wall (Oberdorfer and Buddemeier 1986). The closure of the lagoon corresponds to $\mathrm{t}=0$ and $\mathrm{H}(\mathrm{t})=0$. At each further time step $\Delta \mathrm{t}, \mathrm{H}(\mathrm{t})$ and lagoon height relative to the ocean $\Delta \mathrm{h}(\mathrm{t})$ can be computed by comparing the amount of freshwater added to the lagoon, A $\mathrm{x}(\mathrm{P}-$ E) $\times \Delta \mathrm{t}\left(\mathrm{A}\right.$ is the lagoon surface area, $\mathrm{A} \sim 8 \mathrm{~km}^{2}-$ Jost 2005), and the total amount $\Sigma \mathrm{Q}(\mathrm{z}, \mathrm{t})$ of fresh and salty water leaving the lagoon, where $Q(z, t)$ is the amount of water - fresh or salty 
depending on the position of $\mathrm{z}$ relative to $\mathrm{H}(\mathrm{t})$ - seeping through the lagoon wall between depths $\mathrm{z}$ and $\mathrm{z}+\Delta \mathrm{z}$ during $\Delta \mathrm{t}$ :

$$
\mathrm{Q}(\mathrm{z}, \mathrm{t})=\mathrm{A}_{\mathrm{w}}(\mathrm{z}) \times \Phi(\mathrm{z}, \mathrm{t}) \times \Delta \mathrm{t}
$$

$\mathrm{A}_{\mathrm{w}}(\mathrm{z})$ is the wall surface area between $\mathrm{z}$ and $\mathrm{z}+\Delta \mathrm{z}$ (estimated from the bathymetric map Fig. 1) and $\Phi(\mathrm{z}, \mathrm{t})=\mathrm{K}(\mathrm{z}) / \mathrm{l}(\mathrm{z}) \times \mathrm{h}(\mathrm{z}, \mathrm{t})$ with $\mathrm{K}(\mathrm{z})$ representing the hydraulic conductivity at level $\mathrm{z}, \mathrm{l}(\mathrm{z})$ the wall thickness at $\mathrm{z}$ and $\mathrm{h}(\mathrm{z}, \mathrm{t})$ the hydraulic head at level $\mathrm{z}$ and time $\mathrm{t}$, computed as the hydraulic pressure difference between the lagoon and the ocean at level $\mathrm{z}$ and time t.

Since nothing is known about hydraulic conductivities in the Clipperton atoll, we somewhat arbitrary adopt a negative exponential function $\mathrm{K}(\mathrm{z}) / \mathrm{l}(\mathrm{z})=(\mathrm{K} / \mathrm{l})_{0} \exp \left(-\mathrm{z} / \mathrm{z}_{0}\right)$ to describe the decreasing trend usually observed for permeabilities with increasing depth (Oberdorfer and Buddemeier 1986), where $\mathrm{K}(\mathrm{z})$ is the hydraulic conductivity and $\mathrm{l}(\mathrm{z})$ the lagoon wall thickness at depth z. For $\mathrm{H}(\mathrm{t})$, the best agreement with data (solid black curve in Fig. 2) is obtained for $\mathrm{K}(\mathrm{z}) / \mathrm{l}(\mathrm{z})=1.8 \exp (-\mathrm{z} / 3.5)\left(\right.$ in $\left.^{-1}\right)$. The corresponding time-evolution of the lagoon height relative to the mean ocean level, $\Delta \mathrm{h}(\mathrm{t})$, is also shown in Figure 2 (solid red curve), with an equilibrium height $\Delta \mathrm{h}=0.55 \mathrm{~m}$. Assuming a $50 \%$ interannual variability in rainfall logically induces similar variations in year-to-year lagoon level. However, this does not affect the long-term rate of thickening of the brackish layer which remains unchanged.

With a wall thickness $1(\mathrm{z})$ on the order of $100 \mathrm{~m}$ or so (see Fig. 1), the above exponential law for $\mathrm{K}(\mathrm{z}) / \mathrm{l}(\mathrm{z})$ corresponds to an hydraulic conductivity $\mathrm{K}$ of $180 \mathrm{~m} \mathrm{~d}^{-1}$ at $\mathrm{z}=0,10 \mathrm{~m} \mathrm{~d}^{-1}$ at $\mathrm{z}=-10 \mathrm{~m}$ and $0.6 \mathrm{~m} \mathrm{~d}^{-1}$ at $\mathrm{z}=-20 \mathrm{~m}$. All these values are consistent with hydraulic conductivities measured in various atolls : for instance, at Davies Reef (Australian Great Barrier Reef), Oberdorfer and Buddemeier (1986) measured hydraulic conductivities in the range $100-2000 \mathrm{~m} \mathrm{~d}^{-1}$ for unconsolidated levels and $0.5-10 \mathrm{~m} \mathrm{~d}^{-1}$ for consolidated horizons. In the Cocos (Keeling) Islands, Ghassemi et al. (1999) calculated hydraulic conductivities in 
the range $1.6-650 \mathrm{~m} \mathrm{~d}^{-1}$. Others published values, corresponding to mean hydraulic conductivities, are between $10 \mathrm{~m} \mathrm{~d}^{-1}$ and $60 \mathrm{~m} \mathrm{~d}^{-1}$ (Buddemeier 1981; Parnell 1986).

This negative exponential relationship between $\mathrm{K}$ and $\mathrm{z}$ is clearly greatly oversimplified. Although reefs hydraulic conductivities generally tend to decrease with increasing depth, reefs are hydraulically quite heterogeneous. For instance, hydraulic conductivities measured at Davies Reef (Oberdorfer and Buddemeier 1986) vary over four order of magnitude, with pervious and impervious horizons interspaced down to $-40 \mathrm{~m}$. However, in the case of Clipperton, our simulations rule out any high hydraulic conductivity zone at depth since it would result in a much faster rate of salt expulsion and a thicker freshwater body. Therefore, considering the dramatic lack of data concerning Clipperton, we feel that our choice for $\mathrm{K}(\mathrm{z}) / \mathrm{l}(\mathrm{z})$ is reasonable. The study presented here must therefore be viewed as a simple mathematical model to preliminary describe the first-order hydrological evolution of the lagoon of Clipperton.

Sensitivity tests in which $(\mathrm{K} / \mathrm{l})_{0}$ and $\mathrm{z}_{0}$ were changed by $\pm 50 \%$ around the best estimate show that lagoon height is a quite sensitive geohydrological parameter (Fig. 2). Knowing the mean lagoon height relative to the mean ocean level would therefore have been very useful to put additional constraints on the model. In a similar vein, although possible reverse circulation at rising tide does not affect the long-term evolution of the brackisk layer (which depends primarily on net water fluxes), reliable knowledge of the tidal range, times-series of lagoon level fluctuations and of the spatial distribution of lagoon salinities would also be of great interest in the future to model lagoon hydrology in a more realistic way.

\section{Experimental results}

\subsection{Salinity and $\delta^{18} O$ vertical profiles}


Our 2005 salinity and $\delta^{18} \mathrm{O}$ data are displayed in Table 1 . The salinity of the brackish lens, $S=5.4 \pm 0.2$, is close to the value of $4.4 \pm 0.2$ measured previously (Carsin 1980). This slight presence of salt cannot be explained by salt deposition from marine aerosols since Figure 3 indicates a mixing between between rainwater and ocean water (salt deposition would leave the $\delta^{18} \mathrm{O}$ unchanged). Therefore it must be attributed either to large waves reaching the lagoon during severe storms, as evidenced from seeds and pumices present on the lagoon beach (Sachet 1962) or to a reverse circulation within the permeable upper reef at rising tide (tidal pumping - Lam 1974).

Bottom waters in the TSF have a salinity of $34.0 \pm 0.1$, in reasonable agreement with previous measurements by Carsin, $1980(\mathrm{~S}=34.3 \pm 0.2)$ and consistent with surface ocean salinity $(0-40 \mathrm{~m})$ ranging from 33.3 in September-December to 34.2 in January-March (Levitus et al. 1994). At -20 m in the FO ("Fosse Occidentale" or "Western Deep), the salinity $-\delta^{18} \mathrm{O}$ diagram (Fig. 3) points to substantial mixing between saline and fresh waters. This may be due to the fact that the Western Deep is less confined than the TSF (see Fig. 1), thus favoring wind-induced mixing across the halocline.

Both salinity and $\delta^{18} \mathrm{O}$ values for bottom waters point to a remnant of oceanic waters at the time when the lagoon was still communicating with the surrounding ocean. However, it is not possible to say whether these waters are completely isolated or exchange to some degree with surrounding waters either vertically through ventilation processes across the halocline or horizontally through deep fissures and cracks in the limestone. Tritium, which is a transient tracer released in the hydrosphere by the atmospheric nuclear tests of the 50's and early 60's, can help to discuss this question.

\subsection{Tritium vertical distribution}


Tritium was measured at the CEA-Saclay's noble gas facility using the ${ }^{3} \mathrm{He}$ ingrowth method (Jean-Baptiste et al. 1992). The vertical structure of the tritium concentration (Table 1 and Fig. 4) parallels that of salinity and $\delta^{18} \mathrm{O}$. Tritium concentrations in the freshwater body are quite homogeneous $(0.81 \pm 0.03 \mathrm{TU})$ - $1 \mathrm{TU}$ (Tritium Unit) corresponds to a $\mathrm{T} / \mathrm{H}$ isotopic ratio of $10^{-18}$, showing that this water mass is essentially well-mixed. This value is in good agreement with tritium concentration in precipitation in the Pacific equatorial belt recorded by the IAEA network (Fig. 5). Tritium concentration in the deep saline waters of the TSF is quite low $(0.06 \pm 0.05$ at $-20 \mathrm{~m}$ and $0.03 \pm 0.05 \mathrm{TU}$ at $-25 \mathrm{~m})$, suggesting that this water mass is indeed quite isolated from the surrounding ocean where tritium concentration in the mixed oceanic layer is on the order of $1 \mathrm{TU}$ (Jenkins 2007). Concentration at $-20 \mathrm{~m}$ in the FO is substantially higher $(0.26 \pm 0.05 \mathrm{TU})$, in qualitative agreement with salinity and $\delta^{18} \mathrm{O}$ which point to substantial mixing between fresh and saline waters at this depth.

From the surface down to $-15 \mathrm{~m}$, all tracer vertical distributions are strikingly homogeneous, suggesting that the brackish layer, which floats on top of the denser saline deep layer, is efficiently mixed by the wind. This significant wind-mixing is not surprising considering that Clipperton's lagoon is about $12 \mathrm{~km}$ in circumference, in the middle of the ocean, surrounded by a cay a few meters-high at most.

\section{Ventilation of the halocline and deep saline layers}

\subsection{Vertical diffusion across the halocline}

The interface between the saline deep layer and the freshwater lens on top of it, is characterized by a strong density gradient. Diapycnal fluxes are usually assumed to linearly depend on the gradients; so their formulation is analogous to that of diffusion (Gregg 1987). In this section, we use bomb tritium to infer the possible rate of vertical mixing across the interface of the two water masses. 
The bomb tritium transient started in 1945, reaching a peak value in 1964 at the eve of the atmospheric tests ban treaty (Fig. 5). Pre-nuclear tritium in precipitation is taken at $1 \mathrm{TU}$ (von Buttlar and Libby, 1955; H. Craig and D. Lal, 1961). The time-history of tritium in precipitation is that displayed in Fig. 5. The influence on tritium of the mixing of the freshwater body with surface oceanic water (to create brackish waters with a salinity of 5.4), either by wave surge or by tidal pumping (see $\S 3.1$ ), is taken into account using the timehistory of tritium concentration in the Eastern Tropical Pacific surface ocean (Fig. 5 inset). In the model, the freshwater body is considered as a well-mixed reservoir, as evidenced by the salinity, $\delta^{18} \mathrm{O}$ and tritium vertical homogeneity. On the contrary, transfer across the halocline and downward penetration of tritium in the saline water mass are assumed to be controlled by vertical diffusion.

The tritium simulation starts at the date of lagoon closure (in 1858). As classically done in transient tracer simulations (Heinze et al. 1990; Peeters et al. 1997), the time-evolution of the tritium concentration in the brackish layer is computed at each time step $\Delta \mathrm{t}$ from the difference between the tritium added to the layer by rainwater and surface ocean water inputs and the tritium transferred to the deep layer across the interface by vertical diffusion, plus tritium decay during $\Delta \mathrm{t}$. The deep saline layer is divided into elementary sections of thickness $\Delta \mathrm{z}$. Tritium downward penetration into this deep layer is calculated step by step by establishing the tritium budget in each section $\Delta \mathrm{z}$ :

$$
\mathrm{C}(\mathrm{z}, \mathrm{t}+\Delta \mathrm{t})=[\mathrm{C}(\mathrm{z}, \mathrm{t})+[\mathrm{A}(\mathrm{z}) \times \Phi(\mathrm{z}, \mathrm{t})-\mathrm{A}(\mathrm{z}+\Delta \mathrm{z}) \times \Phi(\mathrm{z}+\Delta \mathrm{z}, \mathrm{t})] / \mathrm{V}(\mathrm{z})] \exp (-\lambda \times \Delta \mathrm{t})
$$

where $C(z, t)$ and $C(z, t+\Delta t)$ are the tritium concentrations at time $t$ and $t+\Delta t, A(z)$ and $A(z+\Delta z)$ are the lagoon surface areas at depths $\mathrm{z}$ and $\mathrm{z}+\Delta \mathrm{z}, \mathrm{V}(\mathrm{z})$ is the volume of the section $\Delta \mathrm{z}$ and $\Phi(\mathrm{z}, \mathrm{t})$ and $\Phi(\mathrm{z}+\Delta \mathrm{z}, \mathrm{t})$ are the tritium fluxes entering and leaving the section, given by the Fick's law : 


$$
\Phi(\mathrm{z}, \mathrm{t})=-\mathrm{D} \times[\mathrm{C}(\mathrm{z}+\Delta \mathrm{z}, \mathrm{t})-\mathrm{C}(\mathrm{z}, \mathrm{t})] / \Delta \mathrm{z}
$$

The thickening of the brackish layer is taken into account at each time step according to Fig. 2.

The vertical diffusion coefficients which produce the best fit to the data (see Fig. 4) are D $=2.5 \times 10^{-9} \mathrm{~m}^{2} \mathrm{~s}^{-1}$ and $\mathrm{D}=5 \times 10^{-9} \mathrm{~m}^{2} \mathrm{~s}^{-1}$ for TSF and FO respectively. Fig. 4 shows that these diffusion coefficients also lead to simulated $\delta^{18} \mathrm{O}$ vertical profiles that match the $\delta^{18} \mathrm{O}$ data quite well. This consistency between the vertical distribution of two tracers with very different boundary conditions is a necessary condition since any discrepancy between both tracers would disqualify the model.

The plot in Fig. 6 provides compelling evidence that a major factor influencing the rate of vertical mixing is the density gradient (the vertical density gradient is related to the static stability of the water column - Broecker and Peng 1982). If we adopt for the halocline a thickness of $5 \mathrm{~m}$ (that is between $-15 \mathrm{~m}$ and $-20 \mathrm{~m}$ ), the corresponding density gradient for the TSF and FO are $4.6 \mathrm{~kg} \mathrm{~m}^{-4}$ and $3.6 \mathrm{~kg} \mathrm{~m}^{-4}$ respectively. As shown in Fig. 6, the low vertical diffusion coefficients inferred from the vertical diffusion model are consistent with the value of the density gradient across the halocline.

\subsection{Vertical intrusions of saline surface oceanic water}

The fact that the upper waters are brackish instead of being pure rainwater clearly points to seawater intrusions into the lagoon. The annual inflow of seawater (with a salinity of $~ 34$ ) necessary to produce a salinity of 5.4 corresponds to $~ 19 \%$ of the annual excess of precipitation over evaporation $(\mathrm{P}-\mathrm{E}=1.1 \mathrm{~m} / \mathrm{yr})$. With a lagoon surface area of $8 \mathrm{~km}^{2}$, this corresponds to an annual inflow of seawater equal to $1.1 \times 8 \times 10^{6} \times 0.19=1.7 \times 10^{6} \mathrm{~m}^{3} \mathrm{yr}^{-1}$. These intrusions may be due to large waves pouring over low and narrow areas of the atoll rim during severe storms and adding salty water to the lagoon, as evidenced from seeds and pumices present on the lagoon beach (Sachet 1962). It may also result from a reverse 
circulation within the permeable upper reef at rising tide since Sachet (1962) reports small amplitude tidal oscillations of the lagoon level. Whatever the pathways for this salty water may be, this marine water is denser than the top layer of the lagoon which is brackish. It is thus negatively buoyant and can sink to deeper levels as observed for instance in the jellyfish marine lake in Palau (Wolanski, pers. comm.), also characterized by a two-layer system, a low salinity surface water and an anoxic, high salinity bottom water. The intruding water plumes should thus spread laterally at their level of neutral buoyancy, which depends on the proportion of upper layer water entrained within each sinking plume (Hickey et al. 2000). This entrainment process decreases the density anomaly, so the plumes will be too light to sink to the bottom and should either mix back into the well-mixed upper layer through vertical mixing by wind or settle at the top of the deep saline layer. This can be visualized quite simply in the laboratory by pouring seawater colored with ink into a tank composed of a freshwater layer floating on top of a seawater layer (Fig. 7). If some plume water settles permanently at the top of the saline deep layer, then the salinity and tracers concentrations between the base of the upper brackish layer and the top of the deep saline layer will not result from vertical diffusion but from the accumulation of an intermediate water mass representing a mixture of sinking surface ocean water and entrained brackish water. The timeevolution of the tritium concentration in this intermediate layer, $\mathrm{C}(\mathrm{t})$, can be calculated from the time-history of tritium in the upper layer and in the surface ocean by numerically solving the following mixing equation :

$$
\mathrm{V}(\mathrm{t}+\Delta \mathrm{t}) \times \mathrm{C}(\mathrm{t}+\Delta \mathrm{t})=\left[\mathrm{V}(\mathrm{t}) \times \mathrm{C}(\mathrm{t})+\Phi \times \Delta \mathrm{t} \times\left(\alpha \mathrm{C}_{\mathrm{ssw}}(\mathrm{t})+(1-\alpha) \mathrm{C}_{\mathrm{ulw}}(\mathrm{t})\right] \exp (-\lambda \Delta \mathrm{t})\right.
$$

where $\alpha$ is the proportion of mixing between surface seawater and upper lagoon water, $\mathrm{C}_{\mathrm{ulw}}(\mathrm{t})$ and $\mathrm{C}_{\mathrm{ssw}}(\mathrm{t})$ are the time-dependent tritium concentrations in the upper lagoon water and in the surface seawater respectively, and $\lambda$ is the radioactive constant for tritium. $t=0$ corresponds to lagoon closure. If we assume that the influx $\Phi$ of water to this intermediate layer is 
constant through time, the volume of the intermediate layer at time $t, V(t)$, is equal to $\Phi \times t$. Hence the above equation can be simplified and rewritten as follows :

$$
\mathrm{C}(\mathrm{t}+\Delta \mathrm{t})=\exp (-\lambda \Delta \mathrm{t})\left[\mathrm{t} \times \mathrm{C}(\mathrm{t})+\Delta \mathrm{t} \times\left(\alpha \mathrm{C}_{\mathrm{ssw}}(\mathrm{t})+(1-\alpha) \mathrm{C}_{\mathrm{ulw}}(\mathrm{t})\right] /(\mathrm{t}+\Delta \mathrm{t})\right.
$$

in which the unknowns $\Phi$ and $V(t)$ have both cancelled out.

Fig. 8 displays the relationship between the tritium concentration in the intermediate layer (in 2005) and the mixing proportion $\alpha$ ( $\alpha=1$ correspond to pure sinking seawater with no mixing). In a sinking plume, the proportion of plume water and entrained ambient water is typically in the range 1:5 - 1:1 (Hickey et al. 2000), corresponding to $\alpha$ between 1/6 and 1/2. This corresponds to a salinity of the intermediate layer in the range $10-20$. Hence, since salinity at $-20 \mathrm{~m}$ is above this range (29.03 and 33.66 in the FO and in the TSF respectively), we can conclude that this intermediate layer is less then $5 \mathrm{~m}$ thick. This small value indicates that most of the intruding seawater mixes back into the brackish layer, presumably by windinduced vertical mixing. With respect to tritium, this range for $\alpha$ corresponds to a tritium concentration between $0.45 \mathrm{TU}$ and $0.6 \mathrm{TU}$ (see Fig. 8). These values fall within the range of the tritium concentrations measured at $\mathrm{z}=-15 \mathrm{~m}$ and $\mathrm{z}=-20 \mathrm{~m}(\mathrm{NB}$ : there is no tritium data between these two depths) and are therefore fully compatible with the tritium data.

On the basis of the available tracer data, we can therefore conclude that the diffusive scenario and the sinking plume scenario are both compatible with the data. In the reality, it seems reasonable to think that both mechanisms are acting together to ventilate the halocline and the deep saline layer. Additional tritium data in the halocline (between $\mathrm{z}=-15 \mathrm{~m}$ and $\mathrm{z}=-$ $20 \mathrm{~m}$ ) would be extremely useful to better constrain both scenarios and to quantify their respective role as ventilation mechanisms.

\subsection{Horizontal intrusion of marine water}

As already noted in $\S 2$, the time-evolution of the upper layer thickness rules out any high hydraulic conductivity zone at depth since it would result in a much faster rate of salt 
expulsion and a thicker freshwater body. Nevertheless, it is possible that some horizontal inflow of oceanic waters may occur at rising tide through cracks and fissures in the limestone below the halocline and concur to the ventilation of the deep saline layer. We again use tritium to estimate the ventilation time of the deep lagoon water that would result from such exchange of water. On the ocean side, water belongs to the oceanic mixed layer, hence its tritium concentration is the same as that of the surface water. The mean tritium concentration of the deep lagoon layer, $\mathrm{C}_{\text {deep }}$, can be calculated from the time-history of tritium in the surface ocean by the following mixing equation :

$$
\mathrm{C}_{\text {deep }}(\mathrm{t}+\Delta \mathrm{t})=\left(\mathrm{C}_{\text {deep }}(\mathrm{t})+\Delta \mathrm{t} / \tau \times\left[\mathrm{C}_{\text {ssw }}(\mathrm{t})-\mathrm{C}_{\text {deep }}(\mathrm{t})\right]\right) \exp (-\lambda \Delta \mathrm{t})
$$

with a ventilation time $\tau$ defined as $\tau=V / \Phi$ where $\mathrm{V}$ is the volume of the deep saline water mass and $\Phi$ is the mean water flux exchanged horizontally through the limestone over the depth of deep layer. $\mathrm{V}$ and $\Phi$ decreases through time as the top of the deep saline layer deepens and the rate of salt expulsion slows down (see Fig. 2). In our calculation, we assume $\Phi$ be proportional to the rate of salt expulsion given by the hydrogeological model (see $\S 2$ ). Fig. 8 displays the simulated tritium concentration in the deep layer (in 2005) for various ventilation times (NB: ventilation time $\tau=V / \Phi$ is expressed using the 2005 values for $\mathrm{V}$ and $\Phi)$. Based on measured tritium concentrations in the deep layer, figure 8 shows that the ventilation time that would result from horizontal exchange is $\sim 2000$ years for the FO and $\sim 10$ 000 years for the TSF.

\section{Conclusion}

Salinity, $\delta^{18} \mathrm{O}$ and tritium were measured in the Clipperton lagoon on two vertical profiles, from the surface down to $-25 \mathrm{~m}$. The present study, based on these measurements and available literature data, leads to the following main conclusions : 
- Historical descriptions of the Clipperton island and lagoon in the XIX ${ }^{\text {th }}$ century appear to converge on the fact that the lagoon became isolated from the surrounding ocean waters in 1858 or very shortly before.

- At lagoon closure, because of the high precipitation rate which largely exceed evaporation, a freshwater lens formed on top of the saline oceanic waters. This freshwater input raised the lagoon level and created a hydraulic pressure head which favored salt expulsion through the permeable walls of the atoll. The thickness of this freshwater body was approximately $14 \mathrm{~m}$ in 1980 and $15 \mathrm{~m}$ in 2005.

- A simple geohydrological modeling of this salty waters expulsion process using Darcy's law give satisfactory results : our simulation describes reasonably well the time-evolution of the thickness of the freshwater body over the last 150 years, with hydraulic conductivities typical of those measured elsewhere on other coral reefs.

- The salinity and $\delta^{18} \mathrm{O}$ of the lagoon deep waters correspond to present day surface ocean waters and support the view that these waters are indeed a remnant of oceanic waters from the time when the lagoon was still exchanging water with the surrounding surface ocean.

- Tritium data also show a sharp contrast between fresh surface waters and deep saline waters. The vertical tritium distribution was used to discuss the main physical processes potentially involved in the slow ventilation of the halocline and deep saline layer, including vertical diffusion, sinking of salty surface water intrusions and deep horizontal exchange through fissures in the limestone :

i) The numerical simulations of the bomb tritium transient and $\delta^{18} \mathrm{O}$ vertical distribution assuming a well-mixed upper layer and downward vertical diffusion across the halocline and in the deep layer, agree reasonably well with the measured concentrations. The vertical diffusion coefficients deduced from those simulations are consistent with the value of the density gradient across the halocline. 
ii) The alternative scenario in which the water layer at the interface between the upper brackish layer and the lower saline layer consists in sinking surface seawater intrusions that settle at the base of the brackish layer, is also consistent with available salinity and isotopic data $\left(\delta^{18} \mathrm{O}\right.$ and tritium).

iii) Direct ventilation of the deep layer by horizontal exchange through fissures in the limestone is a possible mechanism too, corresponding to very long ventilation times of 2000 years for the FO and $~ 10000$ years for the TSF.

These different ventilation mechanisms give results which are all compatible with available tracer data. Quantifying their respective role in the ventilation of the lagoon deep waters would therefore require more data : at the least, a detailed description of the salinity, $\delta^{18} \mathrm{O}$ and tritium vertical profiles across the halocline and the deep layer would be necessary to better constrain the ventilation processes at work in the lagoon. However, acquiring timesseries of physical and tracer data would be the best strategy to learn more about the detailed hydrology of this remote island. 


\section{References}

Belcher, E., 1843. Narrative of a voyage round the world, performed in Her Majesty's ship "Sulphur" during the years 1836-1842. Volume 1, London, 474 pp.

Bigg, G.R., \& Rohling, E.J., 2000. An oxygen isotope data set for marine waters. J. Geophys. Res. 105, 8527-8535.

Broecker, W.S., \& Peng, T.H., 1982. Tracers in the sea. Eldigio Press, Columbia University, Palisades, New York, 690 pp.

Broecker, W.S., Peng, T.H., Ostlund, G., 1982. The distribution of tritium in the ocean. J. Geophys. Res. 91, 14331-14344.

Broc, D., Leclerc, A.M., Jean-Baptiste, P., 1998. Lagoon hydrology and groundwater circulations : a comuter study. In : V.N. Burganos and G.P. Karatzas (Editors), Computational Methods in Water Resources XII, Vol. 2, Computational Mechanics Publications, pp. 543-550 : doi: 10.2495/CMWR980672.

Buddemeier, R.W., 1981. Geohydrology of Eniwetak atoll islands and reefs. International Coral Reef Symposium, Technical Report UCRL-85411;CONF-810547-1, 17 pp.

Carsin, J.L., 1980. Mission de Clipperton : 8-30 mars 1980, hydrologie des eaux du lagon. Service Hydrographique et océanographique de la Marine (SHOM), Paris, 47 pp.

Craig, H., \& Lal, D., 1961. The production rate of natural tritium. Tellus 13, 85-105.

Etienne, J.L., 2005. The Clipperton Expedition, WWWpage, http://www.jeanlouisetienne .com/clipperton/

Fine, R.A, Reid, J.L., Ostlund, H.G., 1981. Circulation of tritium in the Pacific ocean. J. Oceanogr. 11, 3-14.

French Foreign Office, 1912. Mémoire défensif présenté par le gouvernement de la République Française dans le litige relatif à la souveraineté de l'île Clipperton à Sa Majesté 
Victor-Emmanuel III, roi d'Italie, en exécution de la convention entre la France et le Mexique du 2 Mars 1909, Paris, 503 pp.

Ghassemi, F., Molson, J.W., Falkland, A., Alam, K., 1999. Three-dimensional simulation of the Home Island freshwater lens : preliminary results. Environmental Modelling and Software 14, 181-190.

Gregg, M.C., 1987. Diapycnal mixing in the thermocline : a review. J. Geophys. Res. 92 $5249-5286$.

Heinze, Ch., Schlosser, P., Koltermann, K.P., and Meincke, J., 1990. A tracer study of the deep water renewal in the European polar seas. Deep-Sea Res. 37, 1425-1453.

Hickey, B.M., MacCready P., Elliott E., Kachel, N.B., 2000. Dense saline plumes in the Exuma Sound, Bahamas. J. Geophys. Res. 105, 11 471-11 488.

IAEA, 2008. Global Network of Isotopes in Precipitation, Isotope Hydrology Information System (ISOHIS), International Atomic Energy Agency, Vienna, online database, http://www-naweb.iaea.org/napc/ih/HIS_resources_ISOHIS2.html.

Jean-Baptiste, P., Mantisi, F., Dapoigny, A., Stievenard, M., 1992. Design and performance of a mass spectrometric facility for measuring helium isotopes in natural waters and for low-level tritium determination by the ${ }^{3} \mathrm{He}$ ingrowth method. Appl. Radiat. Isot. 43, 881891.

Jenkins, W.J., 2007. P04 tritium data. In : L.D. Talley, M. Sparrow., P. Chapman, J. Gould (Editors), Hydrographic Atlas of the World Ocean Circulation Experiment (WOCE), Volume 2 : Pacific Ocean, International WOCE Project Office, Southampton, UK. Jost, C., 2003. Clipperton : Ile de la Passion, une aire française du Pacifique à protéger. In : "Les aires protégées insulaires et littorales tropicales", Actes du Colloque Dymset, Nouméa, Oct. 2001, CRET, Coll. "Iles et Archipels", 32, pp 223-243. 
Jost, C., 2005. Environnement tropical et développement territorial : systèmes de contraintes et enjeux dans les Suds. HDR thesis, Volume 2, Université Louis Pasteur, Strasbourg, 169 pp.

Lam, R.K., 1974. Atoll permeability calculated from tidal diffusion. J. Geophys. Res. 79, 3073-3081.

Levitus, S., Burgett, R., Boyer, T.P., 1994. World Ocean Atlas 1994, Volume 3 : Salinity. NOAA Atlas NESDIS 4. US Dept of Commerce, Washington D.C., 117 pp.

Oberdorfer, J.A., \& Buddemeier, R.W., 1986. Coral-reef hydrology : field studies of water movement within a barrier reef. Coral Reefs 5, 7-12.

Ostlund, H.G., Grall, C., Brescher, R.E, 1986. Equatorial Pacific tritium, Tritium Laboratory data report $\mathrm{n}^{\circ} 15$, University of Miami, Rosenstiel School of Marine and Atmospheric Science, Miami, Florida, 190 pp.

Parnell, K.E., 1986. Water movement within a fringing reef flat, Orpheus Island, North Queensland, Australia. Coral Reefs 5, 1-6.

Pease, W.H., 1868. On the existence of an atoll near the west coast of America. Proc. Calif. Acad. Sci. 3, 199-201.

Peeters, F., Kipfer, R., Hohmann, R., Hofer, M., Imboden, D.M., Kodenev, G.G., and Khodzer, T., 1997. Modeling transport rates in Lake Baikal : gas exchange and deep water renewal. Environ. Sci. Technol. 31, 2973-2982.

Sachet, M.H., 1962. Geography and land ecology of Clipperton Island. Atoll Res. Bull. 86, 1115.

Skaggs, J.M., 1989. Clipperton : a history of the island the world forgot. Walker Publishing Company, New York, 318 pp.

Von Buttlar, H., \& Libby, W.F., 1955. Natural distribution of cosmic-ray produced tritium. J. Inorg. Nucl. Chem. 1, 75-91. 
Woodruff, S.D., Slutz, R.J., Jenne, R.L., Steurer, P.M., 1987. A comprehensive oceanatmosphere data set. Bull. Am. Meteor. Soc. 68, 1239-1250. 


\section{Figure captions}

Fig. 1 : Map of the Clipperton atoll and lagoon bathymetry, adapted from Jost (2003).

Inset : Belcher's map established in 1839 (Belcher, 1843).

Fig. 2: Simulated time-evolution of the freshwater body thickness (black curves) and corresponding lagoon height relative to mean surface ocean (red curves) using a simple geohydrological model (see text $§ 2$ ). The decreasing trend for hydraulic conductivities with inceasing depth is described by an negative exponential law $(K / l)_{z}=(K / l)_{0} \exp \left(-z / z_{0}\right)$ where $\mathrm{K}$ is the hydraulic conductivity and 1 the lagoon wall thickness. The best agreement with available data (black solid curve) is obtained for $(\mathrm{K} / \mathrm{l})_{0}=1.8 \mathrm{~d}^{-1}$ and $\mathrm{z}_{0}=$ $3.5 \mathrm{~m}$. The corresponding time-evolution of the lagoon height relative to the mean ocean level is represented by the solid red curve. The dashed and dotted curves correspond to sensitivity tests where $(\mathrm{K} / \mathrm{l})_{0}$ (dashed curves) and $\mathrm{z}_{0}$ (dotted curves) are changed by \pm $50 \%$.

$\underline{\text { Fig. } 3}$ : Salinity $-\delta^{18} \mathrm{O}$ mixing diagram. Oceanic salinity and $\delta^{18} \mathrm{O}$ end-members are from Levitus 1994 and Biggs \& Rohling 2000, respectively. The precipitation $\delta^{18} \mathrm{O}$ endmember was estimated from the data of the Global Network of Isotopes in Precipitation (IAEA 2008).

Fig. 4 : Tritium (in black) and $\delta^{18} \mathrm{O}$ (in red) vertical profiles measured in the TSF (open circles) and in the FO (open squares) in 2005. The solid black curves are the result of the bomb tritium transient simulation for the FO (dashed line) and the TSF (solid line), assuming a well-mixed reservoir for the upper layer and vertical diffusion across the halocline and deeper (see text $\S 4.1$ ). The red curves are the simulated $\delta^{18} \mathrm{O}$ vertical profiles using the same model and same vertical diffusion coefficients for TSF and FO as in the tritium simulation. 
Fig. 5 : Time-history of tritium in precipitation for Clipperton, reconstructed from the Global Network of Isotopes in Precipitation (IAEA 2008) using the data from the Guam, Tarawa and Barbados stations. The red and black dashed curves represent the tritium concentrations in the freshwater body and at $-20 \mathrm{~m}$ depth in the FO (multipled by 100) simulated by the vertical diffusion model of $\S 4.1$. Inset : time-history of tritium concentration in the Eastern Tropical Pacific surface ocean (Fine et al. 1981; Broecker et al. 1986; Ostlund et al. 1986; Jenkins 2007).

Fig. 6 : Coefficient of vertical diffusivity versus density gradient. Open squares are the data reported in Broecker and Peng (1982) based on ${ }^{222} \mathrm{Rn}$ profiles in the deep sea and on tritium profiles in lakes thermocline waters. The present data for the halocline waters are represented by the two black diamonds.

Fig. 7 : Laboratory experiment showing a seawater plume (coloured with ink) sinking in a two-layer system : freshwater surface layer and seawater bottom layer.

Fig. 8: In red : Simulated tritium concentration in the intermediate layer (plume water) as a function of the proportion of mixing between sinking plume water (oceanic surface water) and entrained water (brackish water). $\alpha=1$ corresponds to pure plume water with no mixing (see $§ 4.2$ ); In black : Simulated tritium concentration in the lower saline layer as a function of the ventilation time of the deep water mass by horizontal exchange with surrounding ocean waters (see $§ 4.3$ ). 


\section{Table captions}

Table 1: Clipperton lagoon salinity, $\delta^{18} \mathrm{O}$ and tritium 2005 results. $\delta^{18} \mathrm{O}$ and tritium measurements were performed at LSCE (Saclay). Salinities were calculated from chlorinity measurements performed at IFREMER. Error bars on salinity, $\delta^{18} \mathrm{O}$ and tritium are $\pm 0.01, \pm 0.15$ and \pm 0.05 respectively ( 2 sigma $)$. 


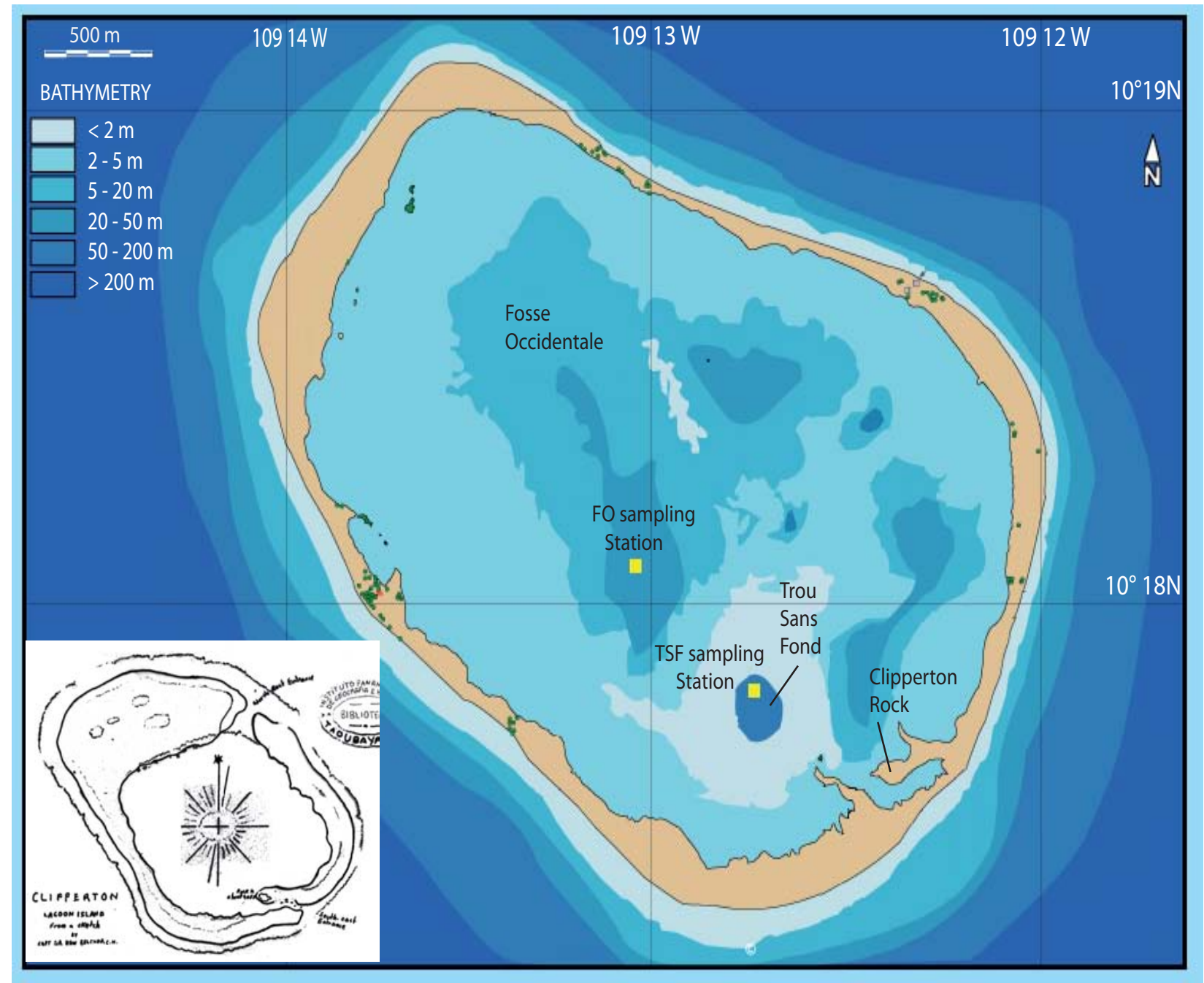




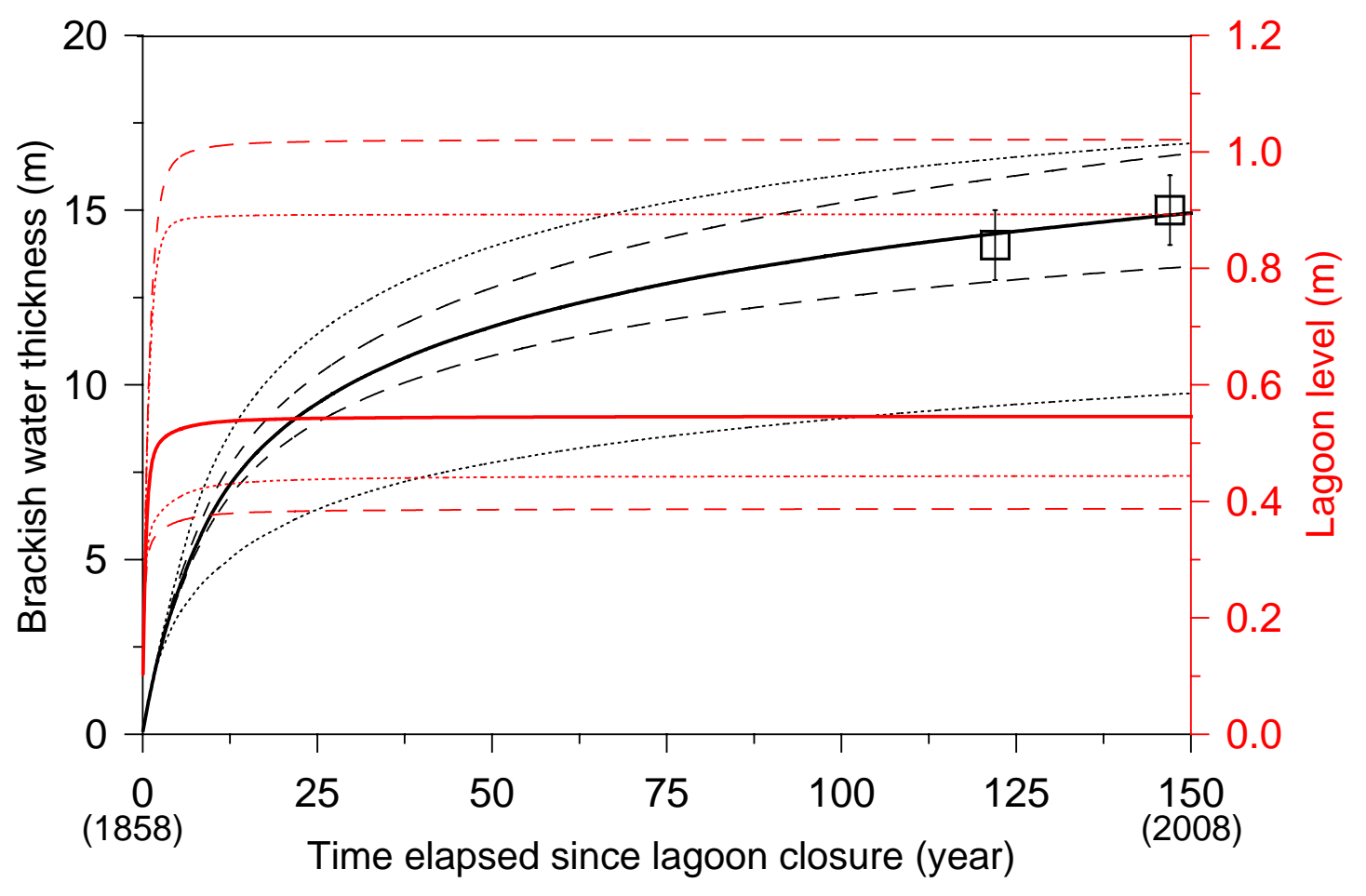

Fig. 2 


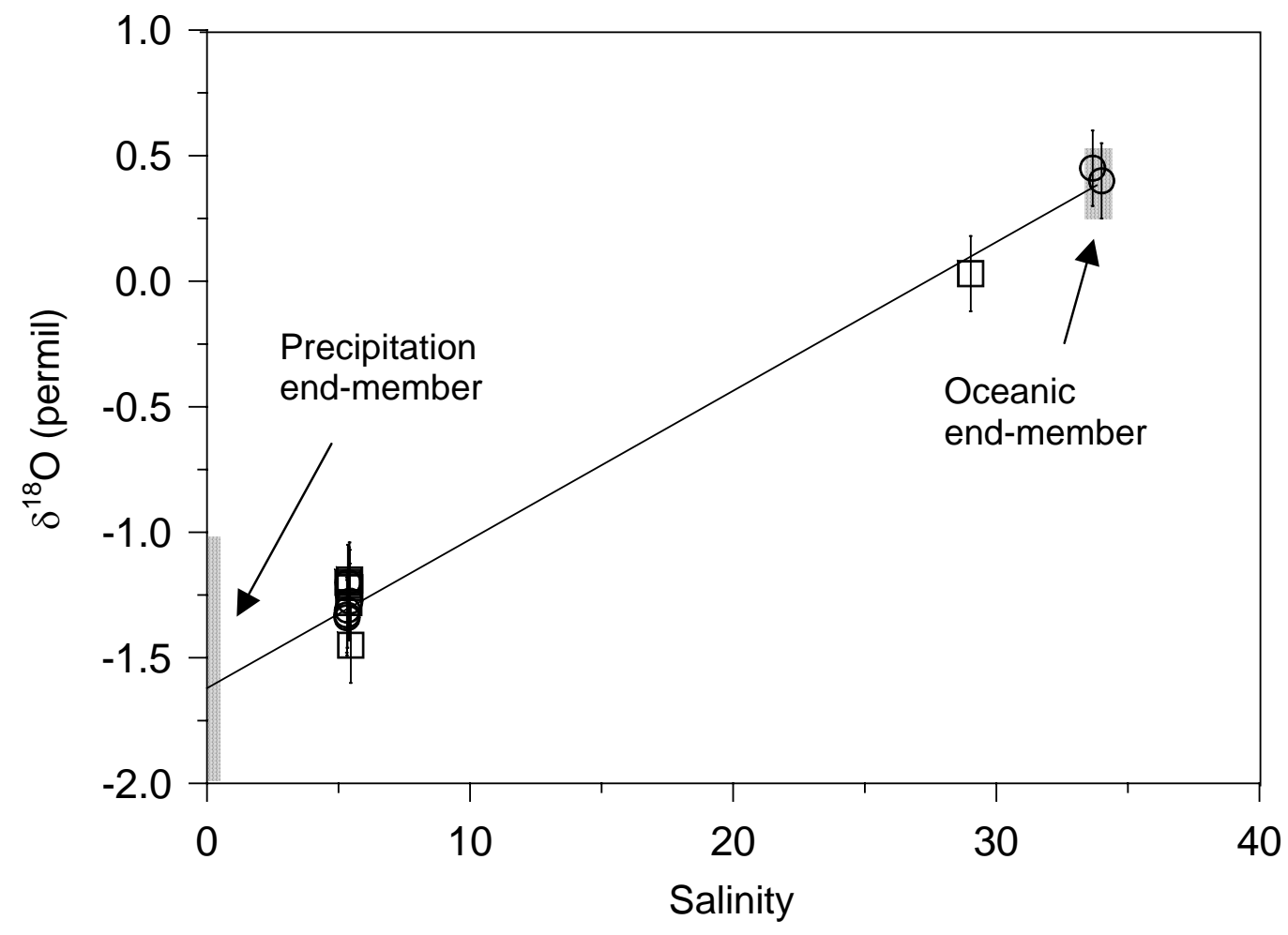

Fig. 3 


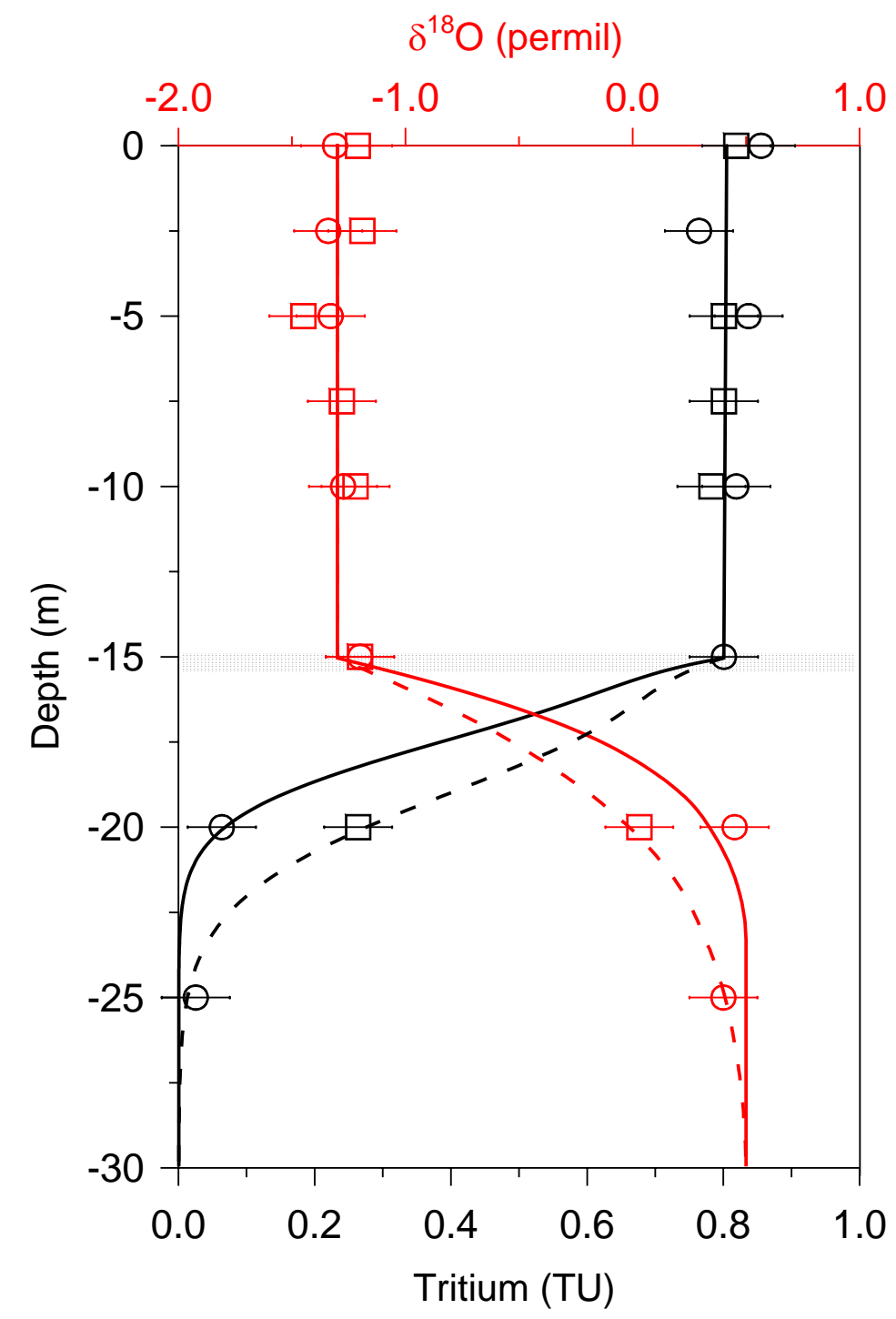

Fig. 4 


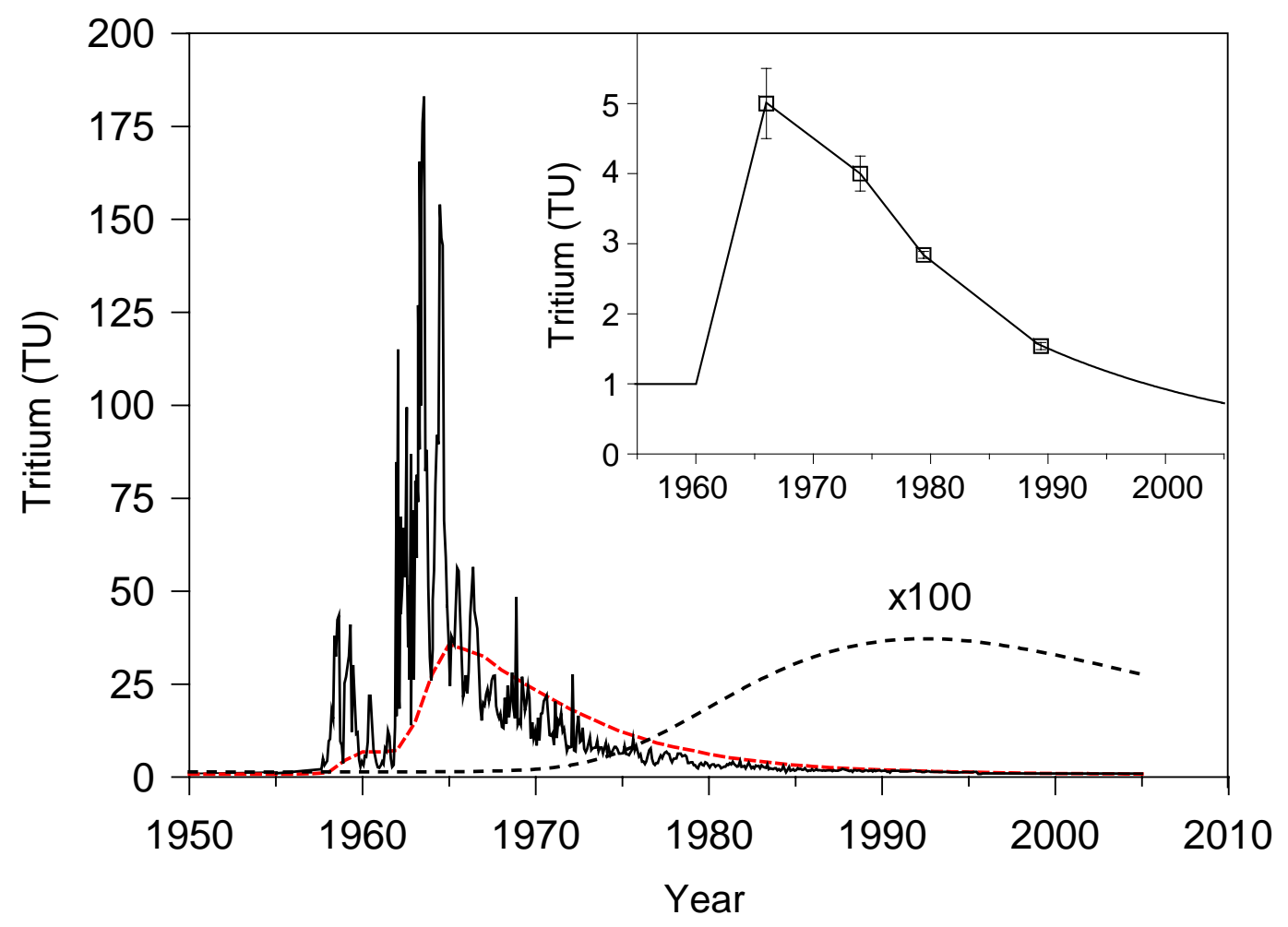

Fig. 5 


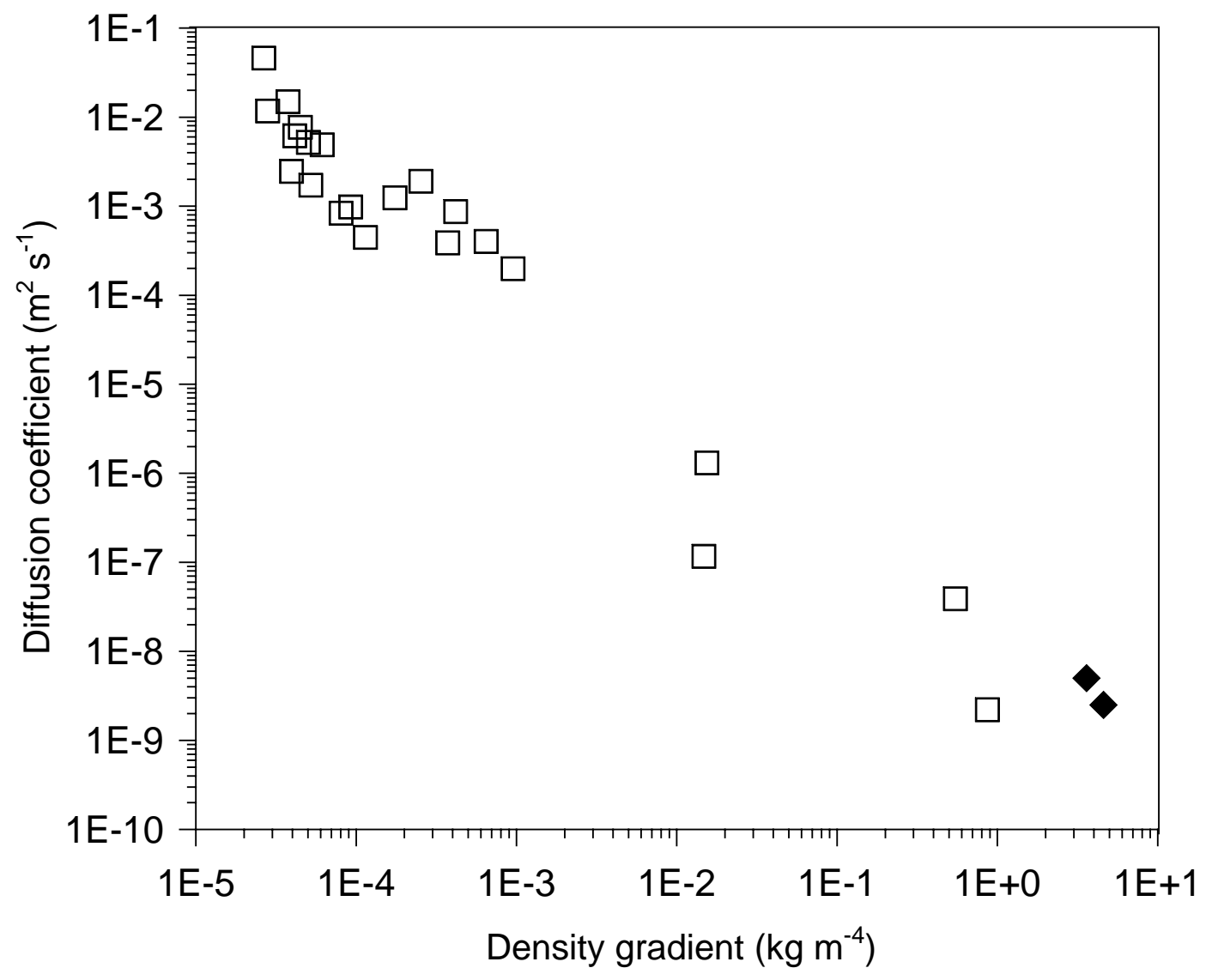

Fig. 6 
A

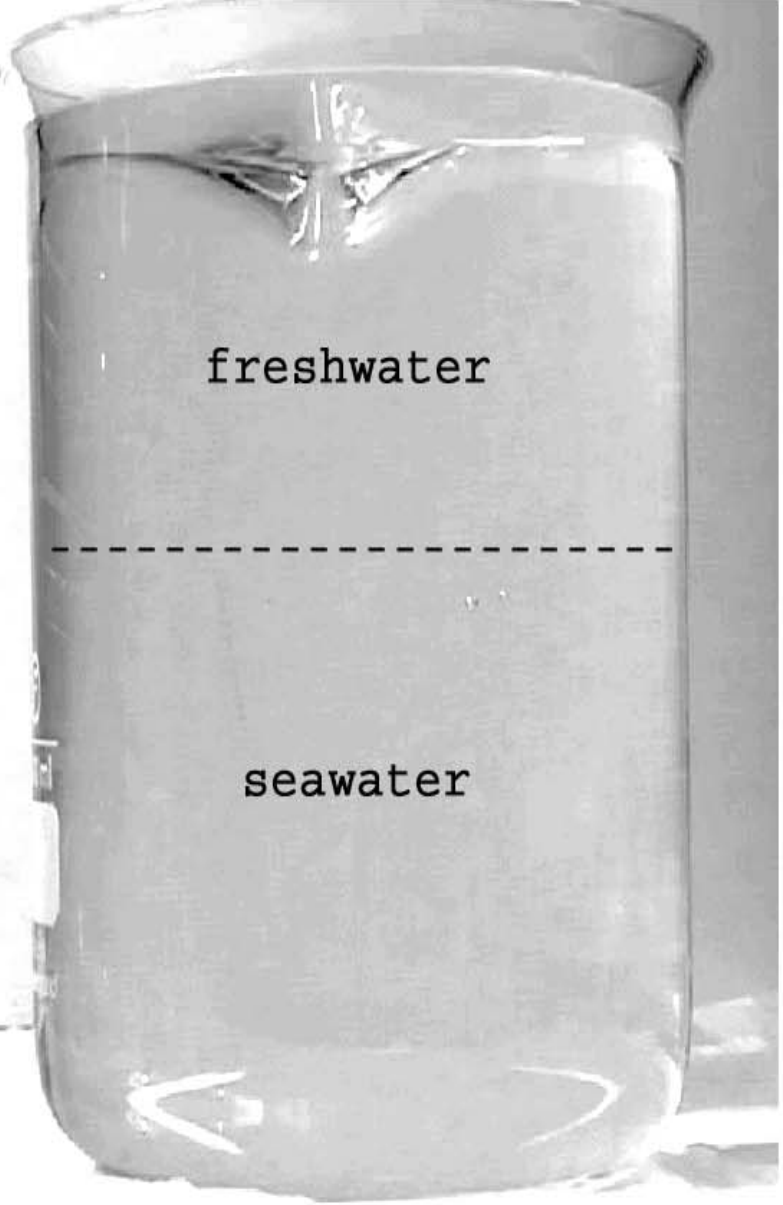

C

seawater
B

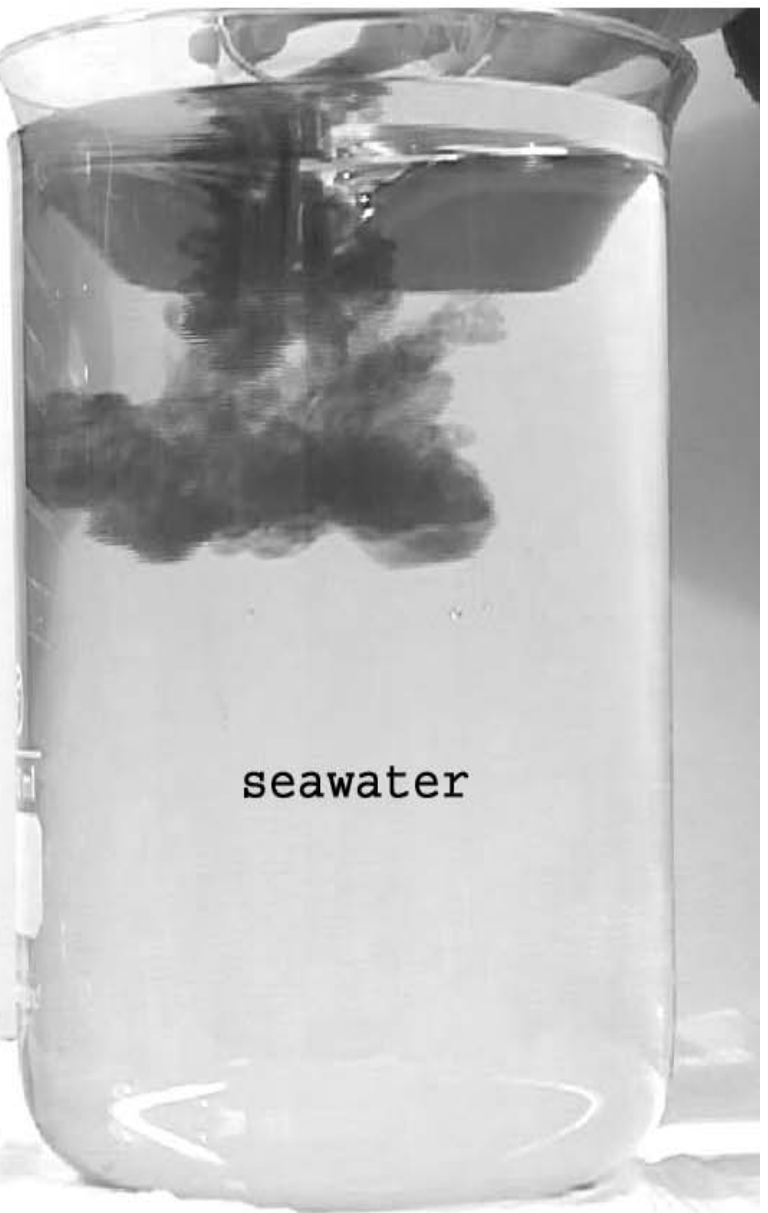

D

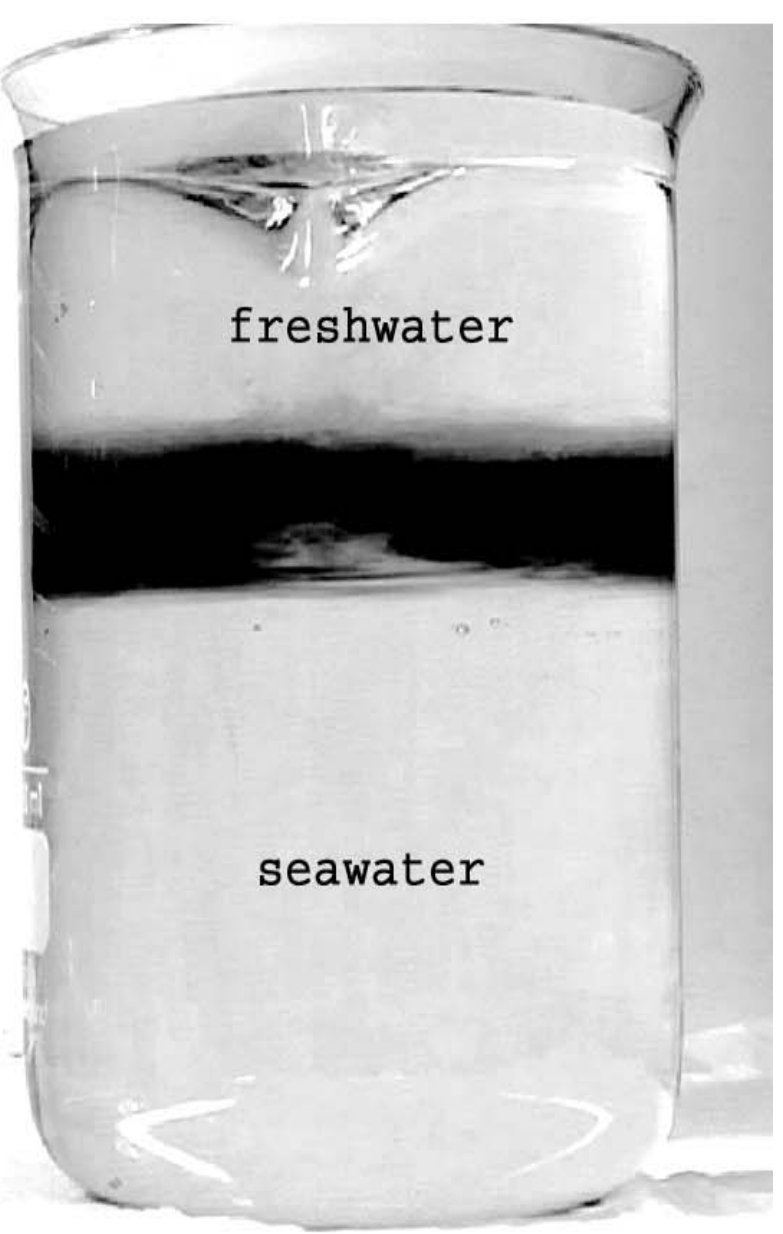




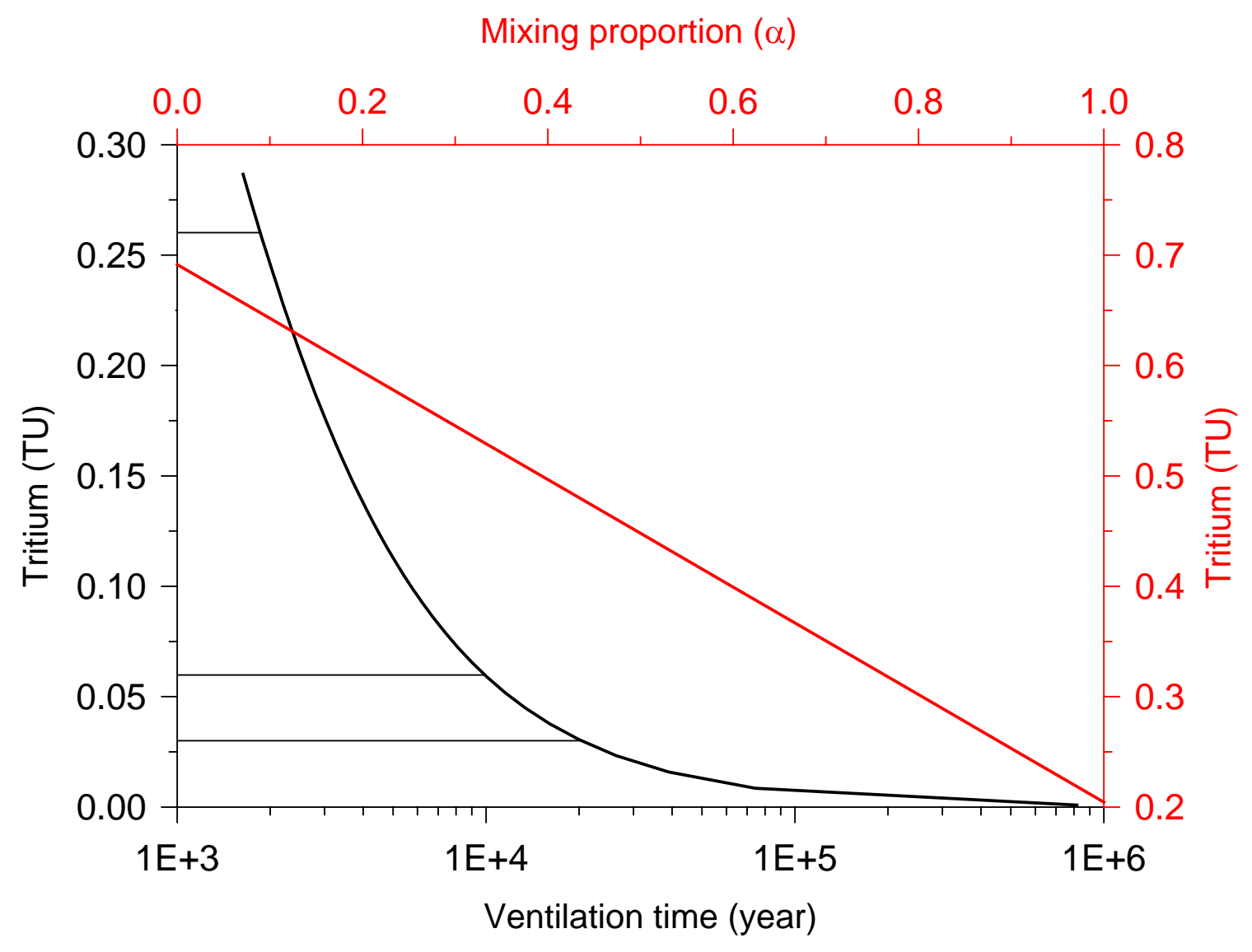

Fig. 8 


\begin{tabular}{|c|c|c|c|}
\hline \multicolumn{4}{|c|}{ Fosse Occidentale (FO) } \\
\hline $\begin{array}{c}\text { Depth } \\
\text { (m) }\end{array}$ & Salinity & $\begin{array}{c}\delta^{18} \mathrm{O} \\
\text { permil }\end{array}$ & $\begin{array}{c}\text { Tritium } \\
\text { (TU) }\end{array}$ \\
\hline 0 & 5.39 & -1.21 & 0.82 \\
\hline 2.5 & 5.42 & -1.19 & 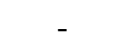 \\
\hline 5 & 5.46 & -1.45 & 0.80 \\
\hline 7.5 & 5.39 & -1.28 & 0.80 \\
\hline 10 & 5.43 & -1.22 & 0.78 \\
\hline 15 & 5.35 & -1.20 & - \\
\hline 20 & 29.03 & +0.03 & 0.26 \\
\hline \multicolumn{4}{|c|}{ Trou Sans Fond (TSF) } \\
\hline $\begin{array}{c}\text { Depth } \\
\text { (m) }\end{array}$ & Salinity & $\begin{array}{c}\delta^{18} \mathrm{O} \\
\text { permil }\end{array}$ & $\begin{array}{c}\text { Tritium } \\
\text { (TU) }\end{array}$ \\
\hline 0 & 5.34 & -1.31 & 0.85 \\
\hline 2.5 & 5.32 & -1.34 & 0.76 \\
\hline 5 & 5.31 & -1.33 & 0.84 \\
\hline 10 & 5.43 & -1.28 & 0.82 \\
\hline 15 & 5.35 & -1.20 & 0.80 \\
\hline 20 & 33.66 & +0.45 & 0.06 \\
\hline 25 & 34.00 & +0.40 & 0.03 \\
\hline
\end{tabular}

